\title{
Penentuan Potensi Batuan Induk Menggunakan Model Log Toc Pada Formasi Ngimbang, Lapangan "Arrazi", Cekungan Jawa Timur Utara
}

\author{
Yosar Fatahillah, Anik Hilyah, Widya Utama \\ Jurusan Teknik Geofisika, Fakultas Teknik Sipil dan Perencanaan, Institut Teknologi Sepuluh \\ Nopember (ITS) \\ Jl. Arief Rahman Hakim, Surabaya 60111 Indonesia \\ e-mail: widya@geofisika.its.ac.id
}

\begin{abstract}
Abstrak-Analisa laboratorium telah membuktikan Formasi Ngimbang sebagai batuan induk yang relatif kaya kandungan organik, ketersediaan data laboratorium terbatas untuk mengukur distribusi kematangan dan kuantitas material organik dalam skala luas cekungan regional. Hal inilah yang menjadi tujuan utama dalam penelitian ini. Dengan demikian dibutuhkan suatu metode sederhana yang terbukti dan akurat mengukur TOC (kandungan karbon organik) pada seluruh kedalaman lubang bor. Penelitian ini mengamati perilaku TOC Model berdasarkan data log sumur. Dengan demikian, akan menghemat banyak waktu dan menekan biaya observasi. Dalam penelitian ini, digunakan metode Passey untuk menentukan besar kandungan karbon organik pada formasi (TOC) dan model Mallick-Raju sebagai indikator kematangan formasi.. Tersedia tiga data sumur dan data batuan inti yang digunakan untuk menentukan model yang paling cocok untuk diterapkan di formasi Ngimbang, Nilai LOM (Tingkat Metamorfisme) diperlukan untuk digunakan pada Passey Model dengan menggunakan crossplot antara DlogR dan TOC dari data inti. Hasil memperlihatkan formasi Ngimbang merupakan formasi dengan rerata kandungan TOC berada pada tingkat buruk - cukup baik dengan tingkat kematangan immature hingga post mature.
\end{abstract}

Kata kunci-TOC, Vitrinite Reflectance, Vshale, $\Delta$ LogR

\section{PENDAHULUAN}

$\mathrm{F}$ TORMASI Ngimbang dikenal sebagai salah satu sumber pasokan utama hidrokarbon di Cekungan Jawa Timur Utara. Penelitian untuk menentukan potensi batuan induk menggunakan pendekatan data well-log mulai berkembang di tahun 1973 menggunakan model Schmoker. Hingga saat ini, beberapa model lain telah diuji keefektifannya dalam mendeteksi kematangan dan jumlah material organik batuan induk. Meskipun tidak jarang persamaan modelnya bersifat empiris dan hanya efektif pada cekungan-cekungan tertentu. Minimnya penelitian tersebut di atas pada formasiformasi batuan induk cekungan di Indonesia, melatarbelakangi penelitian ini.

Terdapat beberapa parameter fisis dan kimia batuan yang perlu untuk diketahui dalam melakukan analisa batuan induk. Komponen terpenting dari analisa batuan induk adalah kuantitas karbon organik dan tingkat kematangannya. Adapaun, parameter fisis yang diteliti dalam penelitian ini adalah besar nilai tingkat kandungan organik karbonnya atau Total Organic
Carbon Content (\%TOC) dan nilai reflektansi Vitrinit (vitrinite reflectance). Sumber informasi sekunder didapatkan dari data batu inti (coring) sebagai data referensi kualitas hasil.

\section{A. Geologi Regional}

Cekungan Jawa Timur Utara terbentuk akibat tumbukan Lempeng Hindia Australia bergerak ke arah utara terhadap lempeng Sunda yang dicirikan oleh anomaly rendah didaerah tumbukan dan anomali tinggi didaerah pegunungan selatan Jawa. Pertemuan kedua lempeng tersebut yang bersifat tumbukan melibatkan kerak samudera lempeng Hindia dan kerak benua dari lempeng Sunda yang membentuk sistembusur kepulauan [1].

Menurut Mudjiono \& Pireno [2] , Ngimbang Eosen diyakini memiliki $95 \%$ sumber minyak dan gas di dalam cekungan Jawa Timur. Total Organic Carbon (\%TOC) di setiap interval ini berkisar dari 1-4 pada batu gamping, dan $0.22-4$ pada batu serpih. Serta, hingga kisaran 7-8 pada batu bara (Coal).

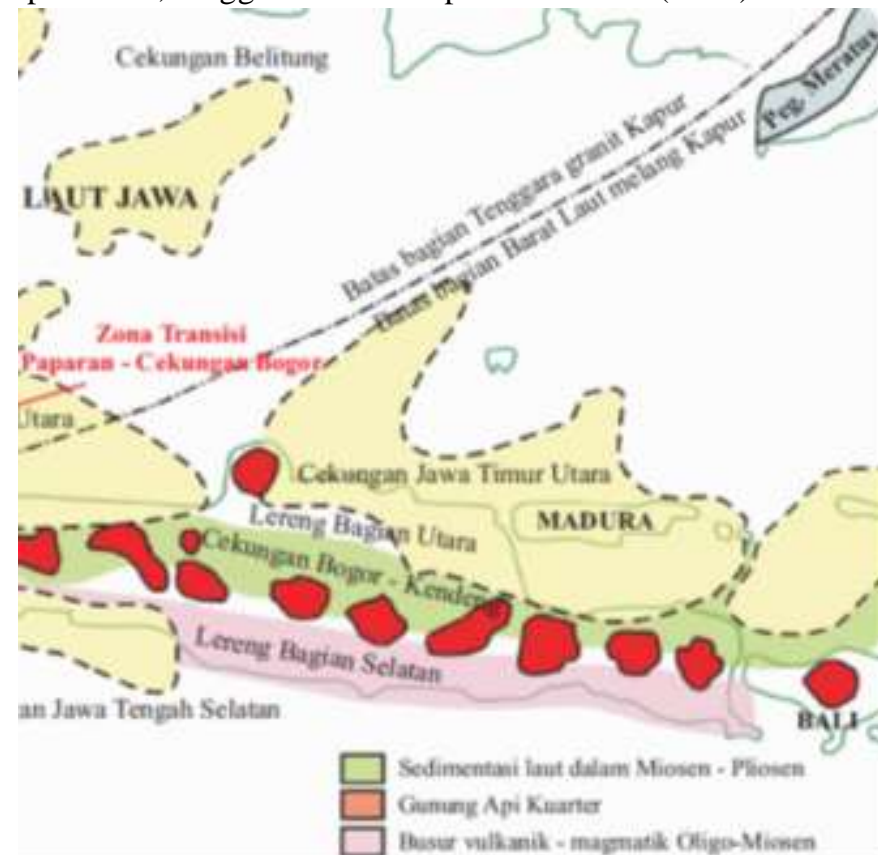

Menurut Satyana dan Purwaningsih [3] pada beberapa analisis batuan sumber di beberapa sumur di Jawa Timur menunjukkan bahwa batuan sumber di beberapa sumur di Jawa 
Timur menunjukan bahwa batuan sumber minyak dan termogenik gas yang potensial di Jawa Timur berasal dari serpih dan batubata pre-Ngeimbang Paleoen - Eosen, Ngimbang Miosen Tengah, Kujung Oligo - Miosen, Tuban Miosen Awal, dan OK Bawah Miosen Tengah.

\section{B. Prinsip Penentuan Volume Batuserpih (Vshale)}

Log gamma ray dapat digunakan untuk menghitung volume lumpur pada porositas reservoir. Volume shale dapat ditunjukkan dengan bilangan pecahan atau bilangan persentasi dan dinotasikan sebagai vshale. Nilai inilah yang digunakan sebagai analisis apakah lapisan tersebut termasuk lapis an shale atau sand. Untuk menghitung besar volume kandungan serpih pada formasi dilakukan penentuan volume shale dari log gamma ray dengan menggunakan persamaan (1) berikut:

$$
\text { Vshale }=\frac{G R-G R \min }{G R \max -G R \min }
$$

dengan IGR = Index gamma ray, GR Log = gamma ray yang terbaca pada log gamma ray, GR max = gamma ray maximu $\mathrm{m}$, dan GR min = gamma ray minimum

\section{Prinsip Kematangan Batuan Induk}

Didasari pada relasi kematangan batuan induk dan kaitannya dengan efek cepat rambat gelombang pada material dengan tingkat kompaksi yang lebih rendah. Akibtanya terjadi penurunan cepat rambat gelombang pada material, yang meningkatkan nilai waktu tempuh gelombang pada batuan. Seiring dengan meningkatnya kedalaman, akan terjadi peningkatan temperatur dan tekanan yang berasosiasi dengan peningkatan posibilitas kematangan batuan induk. Keterkaitan hubungan antara nilai temperatur dan tekanan terhadap kedalaman sumur berisfat linier. Sehingga, persamaan yang digunakan dalam relasi antara log sonik dengan kematangan batuan induk yang diindikasikan berdasarkan nilai pantulan vitrinit juga bersifat linier, sesuai dengan persamaan berikut [4]:

$$
R o=A-B H C / B
$$

\section{Prinsip Metode Passey TOC}

Teknik model Passey dikembangkan pada tahun 1990 oleh Passey dkk [5]. Teknik ini memanfaatkan sifat tahanan jenis formasi dan relasinya degan log densitas, sonic log (waktu transit), dan juga log neutron, terhadap porositas batuan induk. Ide utama dari teknik ini adalah memanfaatkan sifat fluida yang mengisi pori yang terdapat pada batuan induk (ilustrasi gambar. 2).

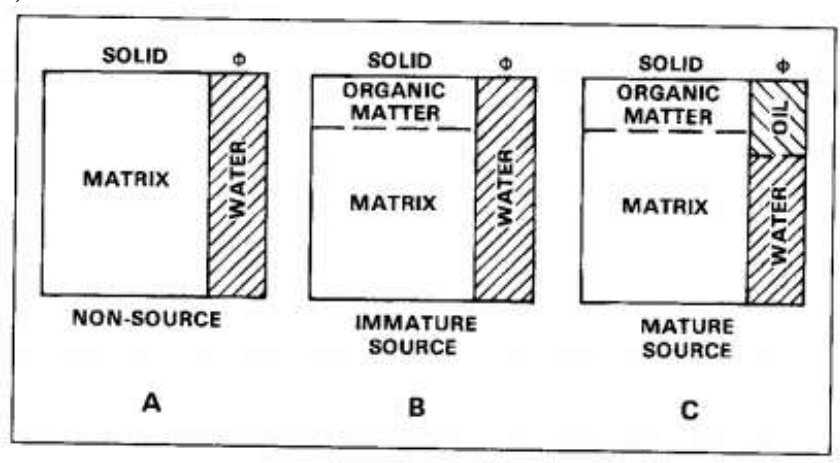

(b)
Gambar. 2. Ilustrasi komponen solid dan fluida pada batuan induk dan nonbatuan induk. (Sumber: Passey, 1990)

Passey menggunakan metode ini, memperkenalkan istilah "Delta LogR" yang nilainya berhubungan secara linear dengan nilai \% TOC dan merupakan fungsi dari kematangan batuan induk. Salah satu variabel utama yang digunakan dari teknik ini adalah nilai log pada baseline (garis basis). Adapun, baseline itu sendiri adalah garis pada kedalam tertentu dimana ditemukan litologi non-batuan induk berbutir halus.

\section{METODOLOGI PENELITIAN}

\section{A. Tahapan Penelitian}

Tahapan metodologi pada penelitian ini dimulai dengan studi literatur dan tinjauan geologi untuk mempelajari karakter fisis formasi batuan induk Ngimbang, parameternya, serta kondisi geologi lapangan penelitian. Tahapan selanjutnya adalah picking interval ketebalan batuserpih (shale) dengan nilai volume lempung Vclay di atas 0.55. Kemudian dilakukan analisa kuantitas karbon organik total (TOC) pada formasi Ngimbang dibarengi dengan kajian geologi pada formasi. Setelah itu, dilakukan analis a kematangan batuan induk dengan menentukan besar kuantitas pantulan vitriti atau vitrinite reflectance (Ro) sebagai parameter kematangan batuan induk. Hasil yang didapat, selanjutnya dianalisa dan ditentukan besar ketebalan pada interval-interval batuan induk berdasarkan kuantitas TOC dan kematangannya.

\section{B. Data Penelitian}

Pada penelitian ini digunakan beberapa jenis data, yaitu data log meliputi log Gamma Ray untuk analisa volume serpih (Vshale) dan $\log$ resistivitas. Serta, log porositas meliputi densitas, dan sonic log. Selain data log digunakan juga data sekunder berupa data mudlog dan geochemistry report untuk dijadikan bahan kajian geologi.

\section{Metode Penelitian}

Langkah pertama dalam penelitian ini adalah menentukan zona-zona batuserpih pada formasi Ngimbang yang memiliki nilai kandungan Vshale diatas 0.55 . Hal ini bertujuan untuk memilah interval-interval yang berlitologi selain batuan induk (misal: batupasir dan batugamping karbonat).

Setelah dilakukan zonasi batuserpih dilakukan pembuatan log model TOC, untuk menentukan persebaran nilai TOC di sepanjang interval formasi Ngimbang pada sumur SH-1. Pembuatan log model TOC dimulai dengan menentukan garis dasar atau biasa disebut sebagai garis baseline.

Baseline dinentukan dengan melakukan plotting antara log sonik (waktu transit) dan log tahanan jenis batuan (resistivity) dimana nilai $100 \mathrm{us} / \mathrm{ft}$ berada pada satu bidang skala yang sama dengan 10 logaritmik log resistivitas. Baseline diambil pada titik bertemunya log sonic dan log resistivitas, dimana log sonic berhimpit dengan posisi di atas garis log resistivitasPengambilan picking interval batuan induk dengan menggunakan plotting antara log resistivitas dan log sonik. Diikuti dengan proses penentuan tingkat kematangan atau Level of Maturity (LOM). 
Setelah dilakukan identifikasi persebaran TOC, dilakukan pembuatan log model untuk parameter kematangan formasi. Yakni, parameter vitrinite reflectance (Ro), dengan mengacu pada persamaan 2. Dimana, persamaan yang didapatkan merupakan persamaan hasil korelasi antara log sonic, dan data Ro core yang tersedia.

Setelah dilakukan seluruh tahap-tahap tersebut, dihasilkan analisa persebaran potensi batuan induk. Dengan parameter tolok ukur-nya adalah nilai kuantitas (TOC) dan kematangan (Ro) interval batuan induk pada formasi.

\section{HASIL DAN ANALISA}

\section{A. Analisa Kandungan Lempung (Vshale)}

Berdasarkan hasil zonasi volume batuserpih didapatkan 4 buah zona denga rerata Vshale di atas 0.55 , seperti pada tabel 1 berikut:

Tabel 1.

Zona Batuserpih

\begin{tabular}{ccccc}
\hline \hline Zona & Kedalaman $(\mathrm{m})$ & $\begin{array}{c}\text { Rerata } \\
\text { Vshale }\end{array}$ & $\begin{array}{c}\text { Vshale } \\
\text { Min }\end{array}$ & $\begin{array}{c}\text { Vshale } \\
\text { Max }\end{array}$ \\
\hline A & $2195-2295$ & 0.574 & 0.359 & 0.947 \\
$B$ & $2387-2461$ & 0.623 & 0.522 & 0.939 \\
$C$ & $2465-2560$ & 0.658 & 0.405 & 0.947 \\
$D$ & $2660-2635$ & 0.591 & 0.212 & 0.910 \\
\hline \hline
\end{tabular}

\section{B. Analisa Kuantitas TOC dan Kematangan Formasi}

Dari masing-masing keempat zona batuserpih sesuaitabel 1 di atas, didapatkan dis tribusi potensibatuan induk sebagaimana berikut:

$>$ Zona A, terdapat 2 buah interval sisipan batubara dan beberapa perlapis an tipis batugamping. Pada zona ini besar nilai kematangan berdasarkan nilai pantulan Vitrinit (\%Ro) berkisar antara 0.68 hingga 1.4 matang hinga sangat matang. Dengan menggunakan metode DlogR didapatkan nilai rerata besar TOC adalah 0.868 wt.\% pada kisaran TOC interval antara 0.276 (TOC minimum pada zona A) dan tertinggi 2.526 (TOC maksimum).

$>$ Zona B, Terdapat sebuah perlapis an batugampis tipis pada kedalaman $2438 \mathrm{~m}$. Pada zona ini besarnilai kematangan berdasarkan nilai pantulan Vitrinit (\%Ro) berkisar antara 0.7 hingga 1.6 atau bersifat matang hinga sangat matang. Dengan menggunakan model Passey metode DlogR didapatkan beberapa zona menarik dimana kemungkinan terdapat lapisan dengan kuantitas TOC nya berada dikis aran $0.34-1.6$

$>$ Zona C, berada pada kedalaman $2387 \mathrm{~m}$ hingga 2461 $\mathrm{m}$. Terdapat satu perlapisan tipis batugamping. Pada zona ini besarnilai kematangan berdasarkan nilai pantulan Vitrinit (\%Ro) berkisar antara 0.9 hingga 1.45 bersifat matang hingga sangat matang. Didapatkan nilai rerata besar TOC adalah 0.812 wt.\% pada kisaran TOC interval antara 0.196 (TOC minimum pada zona A) dan tertinggi 2.995 (TOC maksimum).

$>$ Zona D, besar nilai kematangan berdasarkan nilai pantulan Vitrinit (\%Ro) berkisar antara 1 hingga 1.6 atau sangat matang. nilai rerata besar TOC adalah 0.442 wt.\% pada kisaran TOC interval antara 0.042 (TOC minimum pada zona A) dan tertinggi 1.353 (TOC maksimum).

\section{KESIMPULAN}

Dari Penelitian yang sudah dilakukan dapat diambill kesimpulan bahwa :

1. Model Passey menggunakan metode DlogR memperlihatkan beberapa trend nilai TOC di atas 1.5 atau masuk dalam kategori sangat baik. Namun, ketebalan yang sangat minim (dibawah $2 \mathrm{~m}$ ) mengurangi potensi batuserpih sebagai sumber hidrokarbon batu induk

2. Nilai TOC maksimum yang terdeteksi menggunakan metode DlogR didapatkan pada sumur $\mathrm{SH}-1$ dengan nilai TOC sebesar 4.872 pada zona $B$

3. Kematangan formasi Ngimbang dengan menggunakan analis a Pantulan Vitrinite berada pada zona Matang hingga Sangat Matang pada kisaran nilai Pantulan Vitrinit (Ro\%) dari 0.7 hingga 1.6

\section{DAFTAR PUSTAKA}

[1] Saultan Panjaitan. 2010. Prospek Migas pada Cekungan Jawa Timur dengan Pengamatan Metode Gaya Berat. Bandung: Buletin SumberDaya Geologi Volume 5 Nomor $3-2010$

[2] Mudjiono dan Pireno 2001, Exploration of The North MaduraPlatform, Offshore East Java, Indonesia, Proceedings Indonesia Petroleum Association 28th Annual Convention and Exhibition, Jakarta

[3] Satyana A.H and Purwaningsih, M.E.M. 2003. Geochemistry of theEast Java Basin: New Observations on Oil Grouping, Genetic Gas Types and Trends of Hydrocarbon Habitats, in Proceedings IP A29thConventionand Exhibition, Jakarta

[4] Mallick, R.K., Raju, S.V., 1995. Thermal Maturity Evaluation by Sonic Log and Seismic Velocity Analysis in Parts of Upper Assam Basin, India. Organic Geochemistry 23 (10), 871-879

[5] Passey, Q.R., Moretti, F.U., Stroud, J.D., 1990. A practical modal for organic richness from porosity and resistivity logs. AAPGBulletin 74, 1777-1794. logs II: Geol. Soc. London, Spec. Publ., 65, pp. 369- 376. 